\title{
Changing Trend of Overweight and Obesity and Their Associated Factors in an Urban Population of Bangladesh*
}

\author{
Sumon Kumar Das ${ }^{1}$, Mohammod Jobayer Chisti ${ }^{1}$, Sayeeda Huq ${ }^{1}$, Mohammad Abdul Malek ${ }^{1}$, \\ Lana Vanderlee ${ }^{2}$, Mohammed Abdus Salam", Tahmeed Ahmed ${ }^{1}$, Abu Syed Golam Faruque ${ }^{1 \# \text {, }}$ \\ Abdullah Al Mamun ${ }^{3}$
}

${ }^{1}$ International Centre for Diarrheal Disease Research, Dhaka, Bangladesh; ${ }^{2}$ School of Public Health and Health Systems, University of Waterloo, Waterloo, Canada; ${ }^{3}$ School of Population Health, University of Queensland, Brisbane, Australia.

Email: sumon@icddrb.org, chisti@icddrb.org, sayeeda@icddrb.org, mamalek@icddrb.org, lana.vanderlee@uwaterloo.ca, masalam@icddrb.org, tahmeed@icddrb.org, "gfaruque@icddrb.org, mamun@sph.uq.edu.au

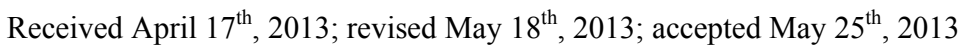

Copyright (C) 2013 Sumon Kumar Das et al. This is an open access article distributed under the Creative Commons Attribution License, which permits unrestricted use, distribution, and reproduction in any medium, provided the original work is properly cited.

\begin{abstract}
There is a scarcity of information examining the prevalence of overweight and obesity in the general population of Bangladesh. Thus, the present study aimed to estimate the changing trends and socio-demographic characteristics of overweight and obese individuals among an urban population in Dhaka, Bangladesh. The present study included data from 49,532 patients enrolled in the Diarrheal Disease Surveillance System (DDSS) at the Dhaka Hospital from 1993-2011. Overweight and obese was categorized among under-5 children $(\mathrm{n}=508), 5-19$ years $(\mathrm{n}=96)$, and $>19$ years $(\mathrm{n}=1330)$. Data was compared with normal weight and malnourished individuals of respective age strata. The proportion of overweight and obese increased from $0.64 \%-5.15 \%$ among children $<5$ years (chi-square for trend $\mathrm{p}<$ $0.001), 0.80 \%-6.70 \%$ among $5-19$ years $(\mathrm{p}<0.001)$, and $3.66 \%-16.94 \%(\mathrm{p}<0.001)$ among $>19$ years. Among those under-5, males $[\mathrm{OR}=1.31(95 \% \mathrm{CI} 1.08,1.57)]$ those with higher socio-economic status $[1.99(1.02,3.82)]$, higher monthly mean family income $[3.76(2.41,5.86)]$, non-slum residence $[2.01(0.74,5.51)]$, high maternal literacy rate $[3.66(2.31,5.79)]$, and using sanitary toilet $[1.47(1.07,2.01)]$ were at higher risk of being overweight and obese compared to well-nourished and malnourished children. Among individuals $5-19$ years, those with higher socioeconomic status and use of sanitary toilet were at higher risk of being overweight and obese. Among those $>19$ years, additionally males were less likely to be overweight and obese [0.59 $(0.49,0.68)]$. Over the last two decades the prevalence of overweight and obesity in Dhaka city has increased at least five folds and it was much higher among those with better socioeconomic status.
\end{abstract}

Keywords: Bangladesh; Obesity; Overweight; Urban

\section{Introduction}

The prevalence of overweight and obesity has steadily increased over the last three decades in most low, middle and high income countries. Obesity is considered as a major health problem, and is associated with serious chronic conditions including diabetes mellitus, hypertension, stroke, cardiovascular disease, and some forms of cancer [1-4]. The World Health Organization (WHO) estimates that by the year 2015, approximately $2-3$ billion adults will be overweight and of these, 700 million

* Conflict of interest: There is no potent conflict of interest to declare. All authors confirm that there is no professional affiliation, financial agreement or other involvement with any company whose product figures prominently in the submitted manuscript.

${ }^{\#}$ Corresponding author. will be obese [5]. Although obesity is generally believed to be a problem among people in higher or middle class living in urban areas, the burden has started shifting towards the poor and rural populations, globally [6]. Due to the higher risk of chronic disease morbidity and mortality, obesity places a large financial burden on the national economy [5,7]. Additionally, obesity is associated with a large psychological burden $[8,9]$.

Overweight and obesity have reached epidemic proportions in many countries in Asia [10]. Importantly, some Asian nations are experiencing a shift towards overweight and obese at a much younger age, compared to those in the Western countries [10]. Among Asian countries, Thailand has the highest rate of obesity, and India has the lowest rates [10]. The prevalence of over- 
weight and obesity is rapidly increasing in China [11], where the prevalence of overweight has increased from $5.3 \%$ to $13.6 \%$ among men and $9.8 \%$ to $14.4 \%$ in women between 1992 and 2002 [12].

To date, there is limited peer-reviewed literature describing the prevalence of overweight and obesity in Bangladesh. Research suggests that the rate of overweight and obesity among urban Bangladeshi women in the reproductive age group increased from $2.7 \%$ in 1996 to $8.9 \%$ in 2006 [13]. A recent study noted that prevalence of obesity was $17.9 \%$ amongst urban school-going children, with higher prevalence among males in this group (19.9\%). Importantly, the highest rate of obesity $(27.7 \%)$ was observed among 6 - 9 year olds [14]. However, there is no such data that indicated the changing trend of overweight and obesity in urban general population in Bangladesh.

Within this context, the present study aimed to assess the burden of overweight and obesity among an urban general population who visited the largest diarrheal disease hospital in the capital city, Dhaka, Bangladesh. The study also aimed to determine the socio-demographic characteristics of overweight and obese individuals, and the changing trends in prevalence over the last two decades.

\section{Materials and Methods}

\subsection{Study Site, Source of Data and the Hospital Surveillance System}

The study was conducted at the Dhaka Hospital of the International Centre for Diarrheal Disease Research, Bangladesh (icddr,b), located in Dhaka, the capital city of Bangladesh. Established in 1962, this hospital currently provides free care and treatment to around 140,000 patients each year, irrespective of age and sex. A Diarrheal Disease Surveillance System (DDSS) has been established at the hospital since 1979, to collect longitudinal data on the hospital's patient populations. The DDSS systematically sampled $4 \%$ of all patients from 1979 through 1995, and since 1996 has sampled 2\% of the patients. The adjusted and reduced sample size was based on increased number of patients (more than doubled) assuming no major changes in the prevalence of different etiologic agents of diarrhea. A trained research assistant interviewed either the patient or the caregiver of young children. We extracted the relevant information on patients enrolled in the DDSS between 1993 and 2011.

\subsection{Definition of Obesity}

Overweight and obesity were defined following WHO guidelines for all age categories [15,16]. Patients were stratified into three age categories: 1) children under 5 years of age, 2) individuals aged 5 - 19 years, and 3) individuals older than 19 years. For children under 5, overweight and obesity was defined using weight-for-age $\mathrm{z}$-score $(\geq+2.00 \mathrm{SD})$. For individuals aged 5 to 19 years, overweight and obesity was defined using BMI-for-age z-score $(>+1.00$ SD). For those older than 19 years, overweight and obesity was defined as a BMI of greater than $25 \mathrm{~kg} / \mathrm{m}^{2}$. Normal weight and underweight were defined as follows: less and 5 years [weight-for-age z-score $(\geq-2.00$ to $<+1.00 \mathrm{SD} ;<-2.00 \mathrm{SD})], 5-19$ years [BMI-for-age $z$-score $(\geq-2.00$ to $+1.00 \mathrm{SD} ;<-2.00 \mathrm{SD})$ ] and above 19 years [BMI $\left(18.5\right.$ to $<25 \mathrm{~kg} / \mathrm{m}^{2} ;<18.5$ $\left.\left.\mathrm{kg} / \mathrm{m}^{2}\right)\right]$, respectively.

\subsection{Sampling Frame}

In total, 49,532 patients were enrolled in the DDSS during the study period (1993-2011). Of these, 26,623 were children less than 5 years old, 6859 were individuals aged 5 - 19 years and 16,050 were individuals older than 19 years. Among these three populations, overweight and obesity together represented $2 \%(n=508), 1 \%(n=96)$ and $8 \%(n=1330)$ of the total population, respectively. The distribution of normal weight among the populations was 51\% $(\mathrm{n}=13,455), 65 \%(\mathrm{n}=4426)$ and 53\% $(\mathrm{n}=$ 8,497 ) for children under 5 , children 5 to 19 , and individuals older than 19 years, respectively. The distribution of underweight among the population was $47 \%$ ( $\mathrm{n}=$ $12,660), 34 \%(n=2337)$ and $39 \%(n=6223)$ among the respective age categories.

\subsection{Data Analysis}

All data were analysed using Statistical Package for Social Sciences (SPSS) Windows (Version 15.2; Chicago, IL) and Epi Info (Version 6.0, USD, Stone Mountain, GA). Differences in proportions were assessed using Chi-square tests, with a probability of $<0.05$ considered as statistically significant. Strength of association was determined using odds ratios (OR) with 95\% confidence interval (CI). We computed Chi-square tests to test statistical significance in changing trends, assuming that the sample was random, each observation was classified into one cell only, and sample size was sufficiently large with adequate cell counts of 5 or greater in all cells. Finally, separate multinomial logistic regression analyses were performed for each age stratum. In the analysis, nutritional status (overweight or obese and underweight) was considered as the dependent variable, using normal weight as the reference variable. Socio-demographic factors were included in the regression analysis to identify variables independently associated with overweight and obesity. In the analysis, only those variables which were identified to be independently associated in univariate analyses were included in multinomial models. 


\subsection{Ethical Statement}

The Diarrheal Disease Surveillance System (DDSS) of icddr,b is a routine ongoing activity of the Dhaka Hospital which has been approved by the Research Review Committee (RRC) and Ethical Review Committee (ERC) of icddr,b. At the time of enrollment, verbal consent was taken from the patients or the caregivers or guardians on behalf of the patients. The information was stored in the hospital database and used for conducting research. The DDSS of icddr, $b$ is a scheduled activity on the hospital patients, and previously was performed after taking verbal consent from the parents or guardians of the patients following the hospital policy. Parents or guardians were assured about the non-disclosure of information collected from them, and were also informed about the use of data for analysis and using the results for improving patient care activities as well as publication without disclosing the name or identity of their children. ERC was satisfied with the voluntary participation, maintenance of the rights of the participants and confidential handling of personal information by the hospital physicians and has approved this consent procedure.

\section{Results}

From 1993 to 2011, the proportion of overweight and obese children under five years of age increased from $0.64 \%$ to $5.15 \%$ (chi-square for trend $\mathrm{p}<0.001$ ) (Figure 1). Among patients aged 5 to 19 , the proportion of overweight and obese increased from $0.80 \%$ to $6.70 \%$ (chisquare for trend $\mathrm{p}<0.001$ ), and from $3.66 \%$ to $16.94 \%$ among those older than 19 years (chi-square for trend $\mathrm{p}<$ 0.001) during the study period (Figure 1). Between these periods, a sharp increasing trend was observed after 2006 among individuals from all age groups.

Among under-5 children and 5 to 19 years group, males were more likely to be overweight and obese compared to females; however, among those more than 19 years of age, females were more overweight and obese then males (Figure 2).

There was also a significant change in the proportion of normal weight individuals across all age strata. Mean weight-for-age score among under-5 children was -1.086 in 1993, and increased to -0.790 in 2011 ( $\mathrm{p}<0.001,95 \%$ CI: $-0.43,-0.30)$. For the $5-19$ years age group change in BMI for z-score increased from -1.077 to $-0.742(\mathrm{p}<$ $0.001,95 \%$ CI: $-0.46,-0.21)$ and for individuals aged above 19 years, there was an increase in BMI from 20.665 to 21.314 ( $<<0.001,95 \%$ CI: $-0.85,-0.45$ ) over the period (Figure 3).

Only $1 \%$ of overweight and obese under-five children were slum dwellers, and about $65 \%$ of them were males. There were significantly higher proportions of overweight and obese among under-5 children from families with better socioeconomic status, those with smaller family size, and those with high maternal literacy. Those who used sanitary toilet facilities and boiled water for drinking were also more likely to be overweight and obese, compared to those with well-nourished and malnourished children of this age group (see Table 1). In multinomial logistic regression among children less than five years of age, males, those with better socioeconomic status with high monthly income, living in the nonslum urban residential area, with high maternal literacy rate, who use sanitary toilet and who boiled drinking water were at greater risk of becoming overweight and obese compared to well-nourished and malnourished children (Table 1). Over the study period, it was observed that the proportion of overweight and obese individuals that presented in the hospital with high socioeconomic status increased from $15 \%$ to $27 \%$ (chi-square for trend $p<0.001$ ) among under- 5 children. Similarly, an increased trend was also found for individuals aged $5-19$ years [15\% to $40 \%$; (chi-square for trend $\mathrm{p}<0.001$ ) and those more than 19 years age group [14\% to $24 \%$ (chi-square for trend $\mathrm{p}<$ 0.001)] respectively (data not presented).

Univariate analyses indicated that all the explanatory variables that were found to be significantly associated with overweight and obesity among children less than 5 years old were also significantly associated with overweight and obesity for individuals aged $5-19$ years, (Table 2). However, most of these dropped out when entered into the multinomial model, with the exception of those with smaller family size and those who used boiled water for drinking were at higher risk for the overweight and obesity (Table 2).

Similar findings were also observed for individuals aged 19 years and above, with the only exception being that males were $44 \%$ less likely to be overweight and obese than females (Table 3).

\section{Discussion}

Like many other developing countries, the prevalence of overweight and obesity among the general population is increasing in Bangladesh. From a database with systematic sampling of the Diarrheal Diseases Surveillance System (DDSS) of the Dhaka Hospital of icddr,b, this study found a gradual increase in the proportion of patients with overweight and obesity over the last two decades.

Obesity and overweight results from an imbalance between calories consumed and calories expended. Increased intake of energy-dense foods, and reduced physical activities due to sedentary work, changing modes of transportation, such as stress, lack of sleep and urbanization are among the frequently cited risk factors for overweight and obesity. Children are increasingly exposed to high-fat, high-sugar, high-salt, energy-dense, and micronutrient-poor foods $[17,18]$. These dietary patterns and 


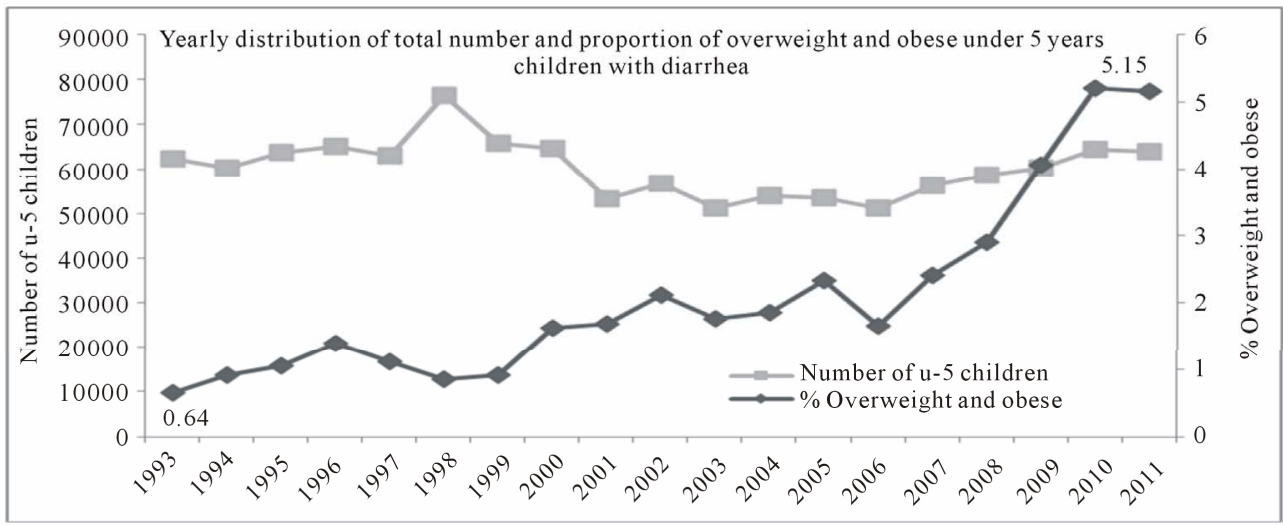

(a)

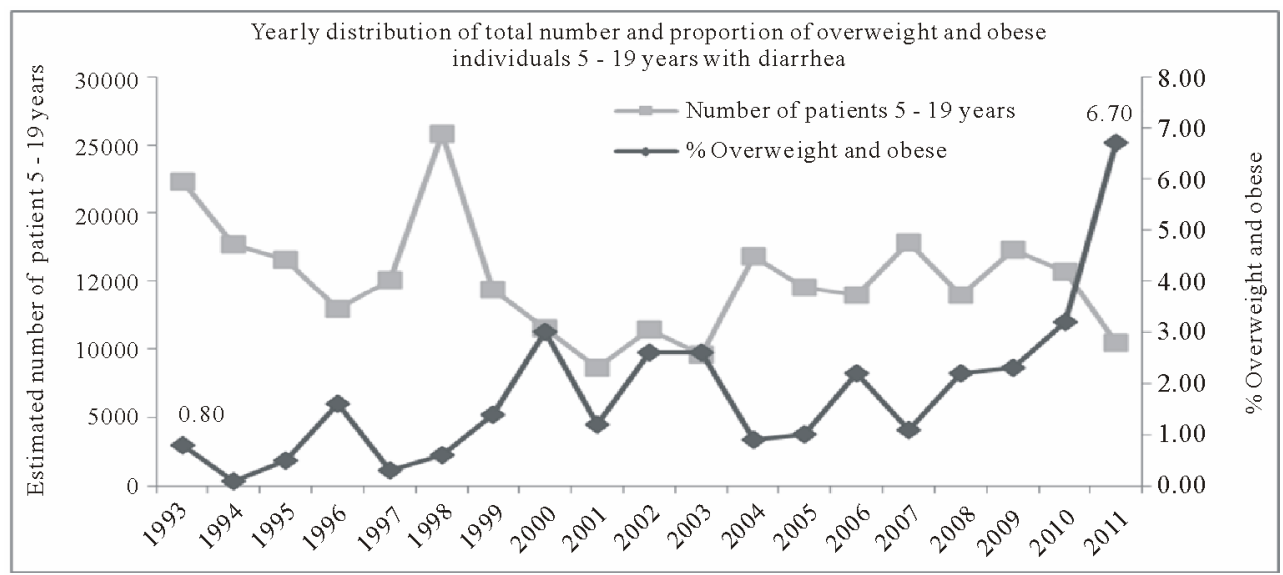

(b)

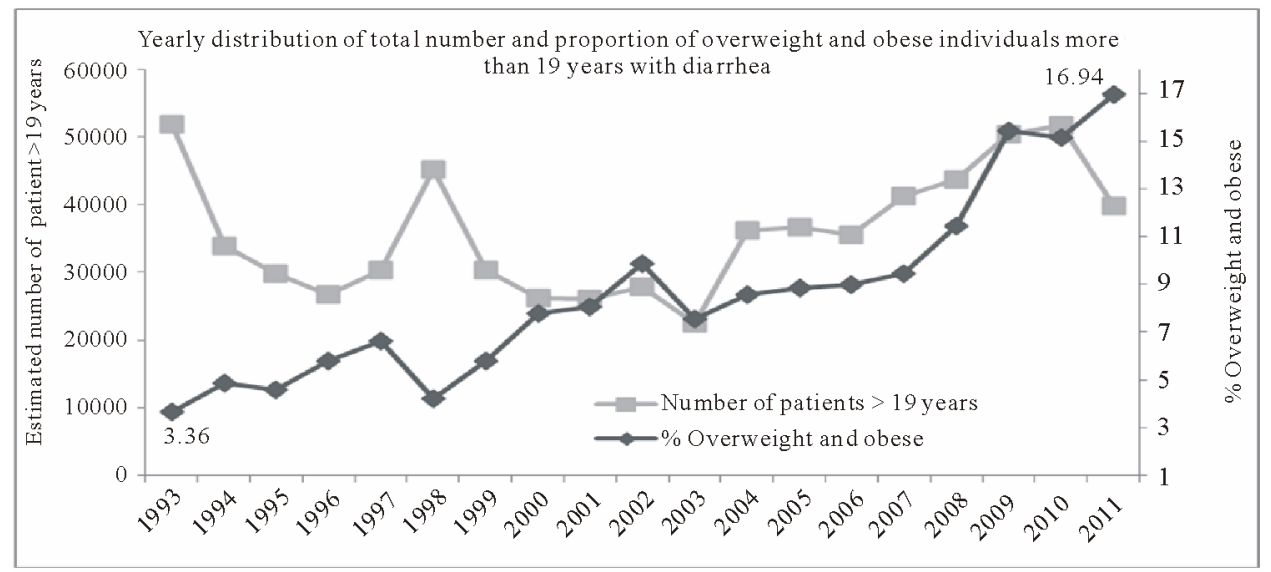

(c)

Figure 1. Yearly distribution of total number and proportion of overweight and obese patients with diarrhea who attended Dhaka Hospital (1993-2011).

low levels of physical activity or increased sedentary behavior can result in sharp increases in childhood obesity as well as obesity among the general population [19].

We have noted that male sex, higher socioeconomic status, and living in non-slum areas are independently associated with overweight and obesity both in the univariate and in the multivariate analysis [20,21]. However, in different settings females have been reported to be at higher risk for obesity [22-24]. With an estimated current population of 12 million [25], Dhaka ranks $11^{\text {th }}$ largest city in the world, and it is expected to be the home of 25 million people by 2025 [26]. This rapid urbanization has been associated with reduced open spaces. Environmental pollution [27,28], climate change [29,30] and increasing 


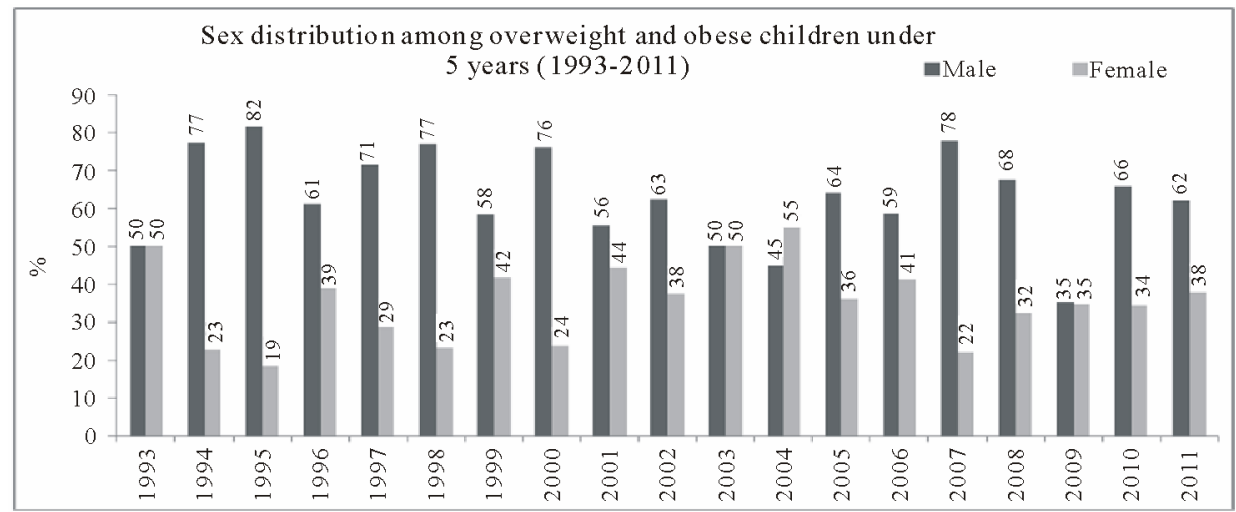

(a)

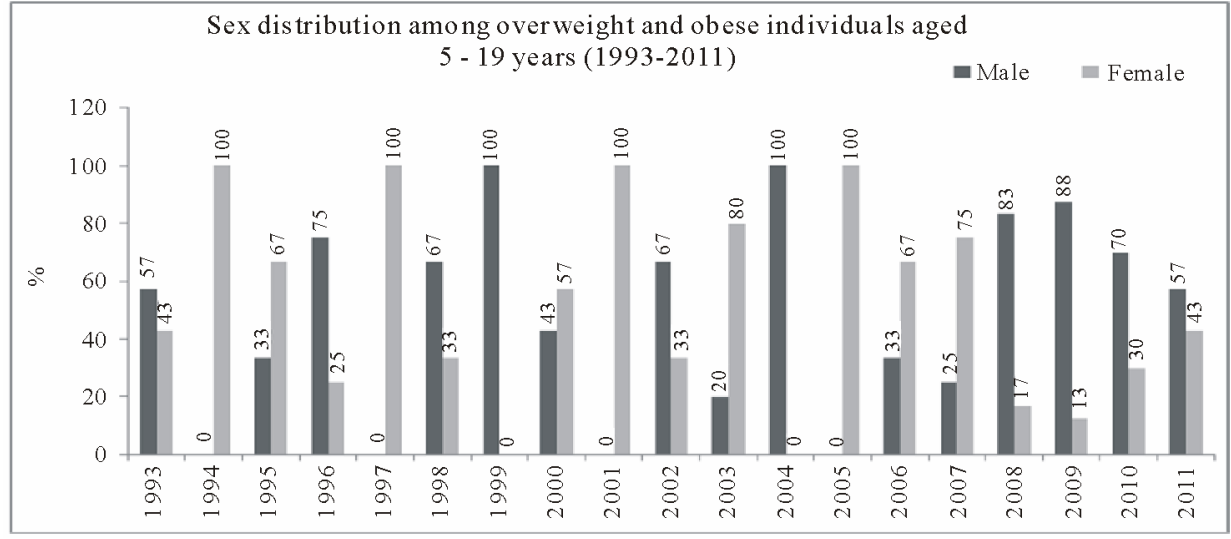

(b)

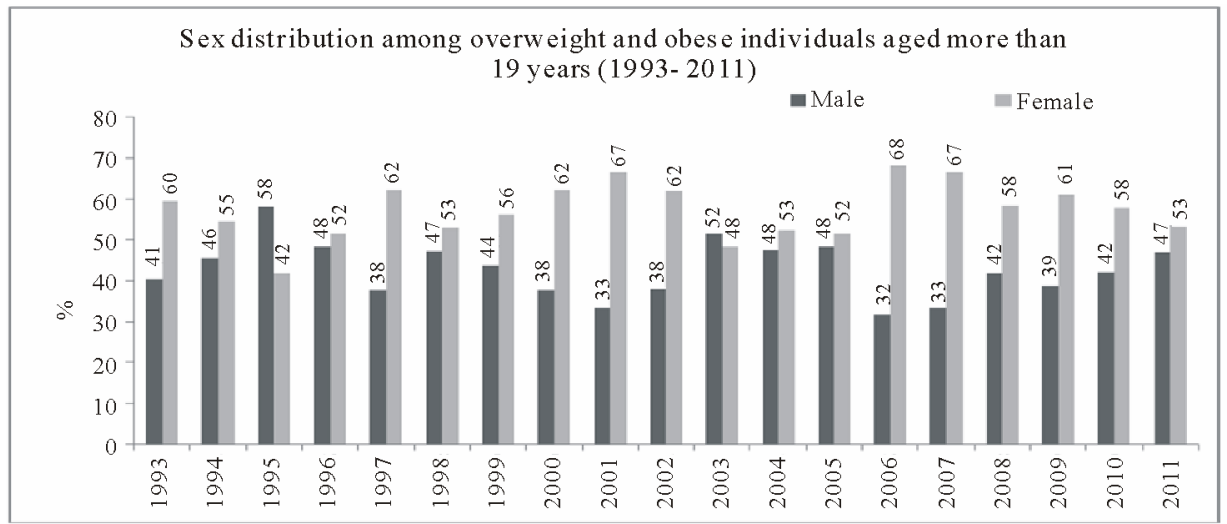

(c)

Figure 2. Yearly sex distribution among overweight and obese individuals in three different age categories who attended Dhaka Hospital (1993-2011).

access to day-to-day modern amenities may also contribute to promoting sedentary lifestyles. Additionally, changes in dietary habits especially of children and young adults towards non-traditional foods with higher amounts of fats $[31,32]$ may also be contributing to the increase in overweight and obesity. The present study found that males less than 19 years were more likely to be overweight and obese which has also been reported in other studies [33]. It is perhaps not a surprising that males aged more than
19 years had a $44 \%$ lower risk of being overweight and obese. Some potential explanations for these sex differences include physiological differences between males and females, use of contraceptive pills among this age group [34], and decreased outdoor physical activity levels due to increased household responsibilities among females. However, males are the main earning source of the household earning, which often means they are engaged with hard labor. 


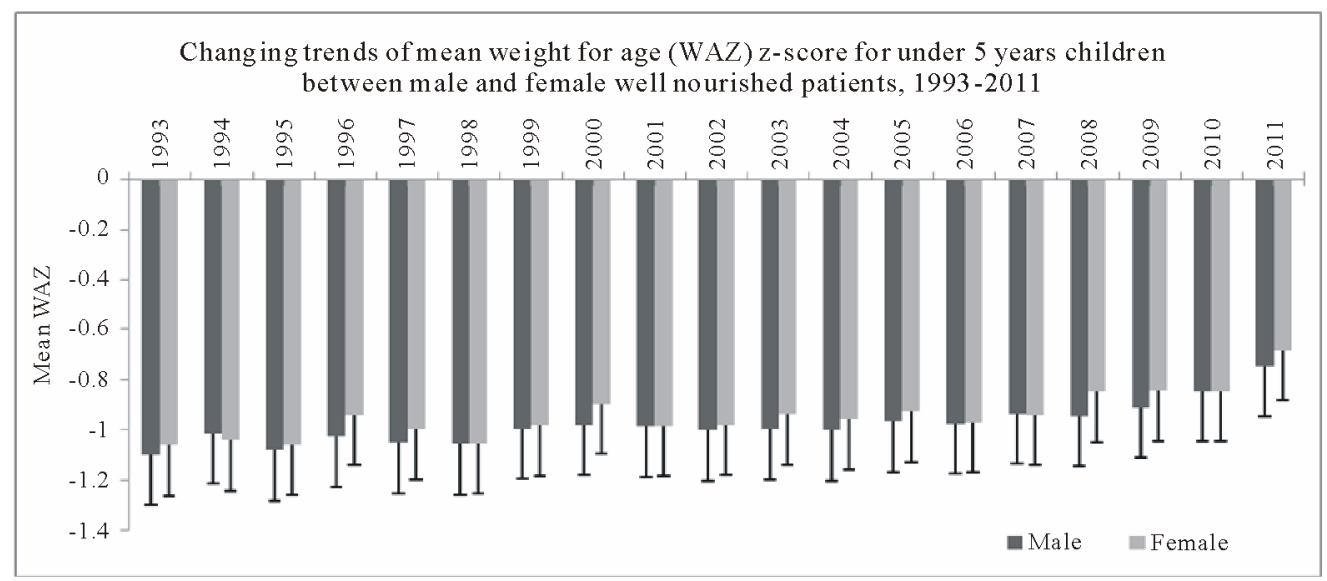

(a)

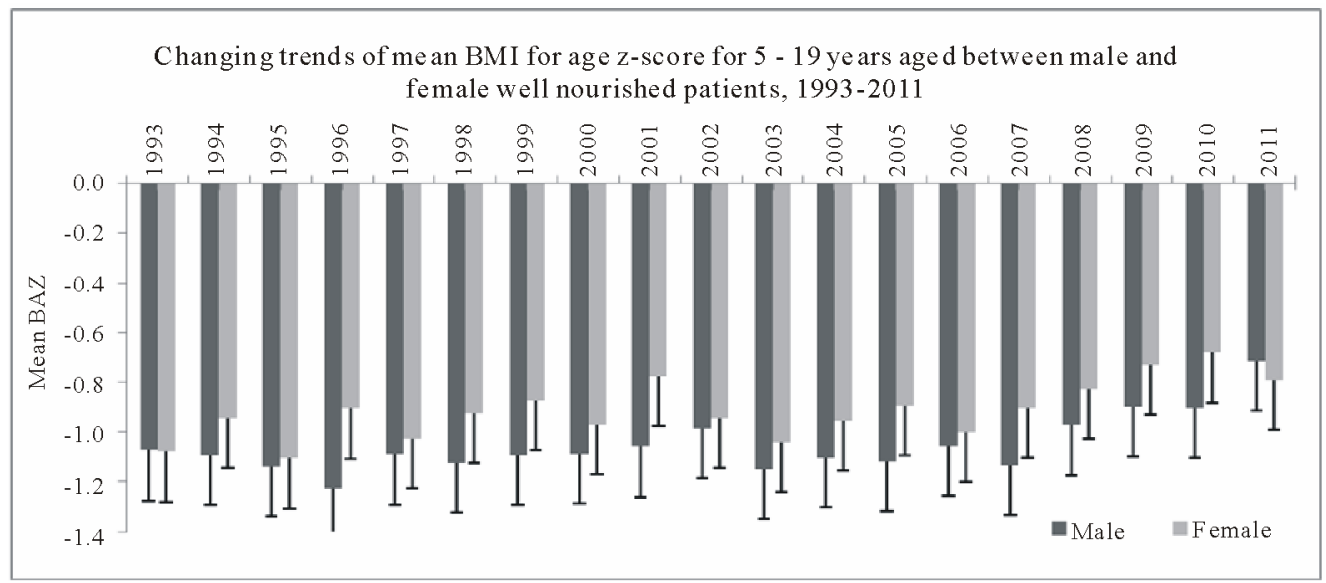

(b)

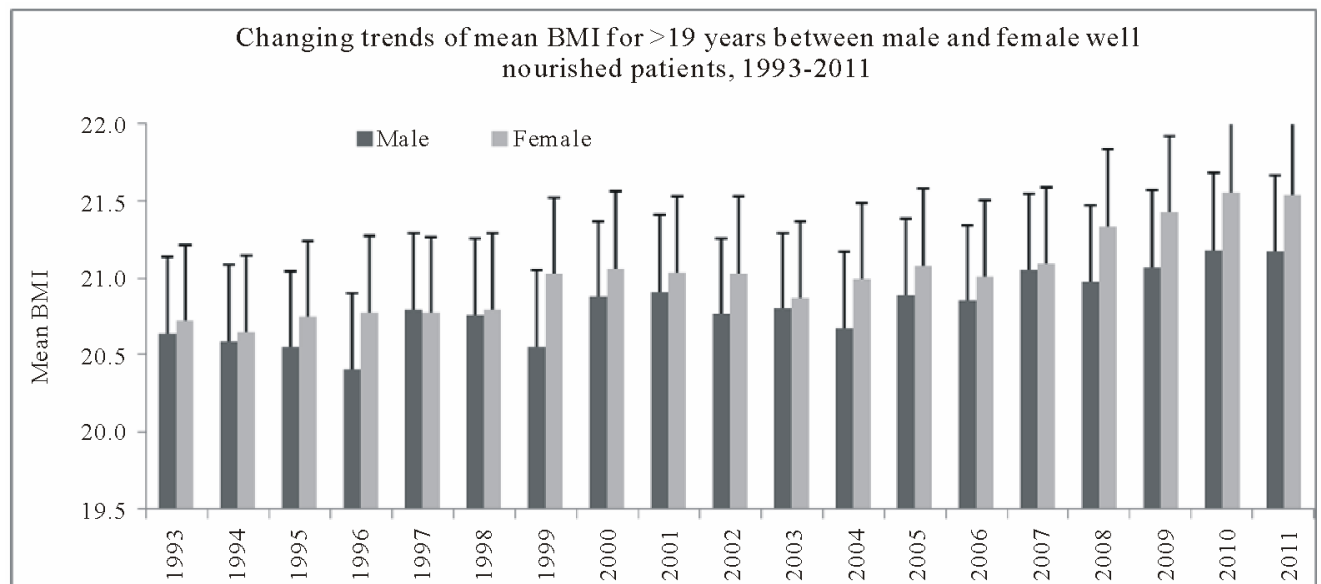

(c)

Figure 3. Yearly change of mean nutritional status among well-nourished individuals in three different age categories who attended Dhaka Hospital (1993-2011).

In the present study, the only factors significantly associated with overweight and obesity in the multinomial regression analysis were high monthly income and practice of drinking boiled water among the $5-19$ year age group, despite significant differences in the univariate analysis. Use of boiled drinking water and sanitary toilet were the proxy indicators of better socioeconomic status, and may also serve as a proxy measure for both increased access to food and consumption of more energy-dense foods. 
Table 1. Socio-demographic characteristics and their association with overweight/obese and malnourished status among under-5 children.

\begin{tabular}{|c|c|c|c|c|c|c|c|c|}
\hline \multirow{2}{*}{$\begin{array}{l}\text { Socio- } \\
\text { demographic } \\
\text { characteristics }\end{array}$} & \multirow{2}{*}{$\begin{array}{l}\text { Overweight } \\
\text { and obese } \\
\begin{array}{c}n=508 \\
(\%)\end{array}\end{array}$} & \multirow{2}{*}{$\begin{array}{c}\text { Well } \\
\text { nourished } \\
\text { n= } 13,455 \\
(\%)\end{array}$} & \multirow{2}{*}{$\begin{array}{c}\text { Malnourished } \\
\mathbf{n}=12,660 \\
(\%)\end{array}$} & \multirow{2}{*}{ p value } & \multicolumn{2}{|c|}{ Overweight and obese } & \multicolumn{2}{|c|}{ Malnourished } \\
\hline & & & & & $\begin{array}{c}\text { Unadjusted } \\
\text { OR (95\% CI) } \\
\text { p value } \\
\end{array}$ & $\begin{array}{c}\text { Adjusted } \\
\text { OR (95\% CI) } \\
\text { p value } \\
\end{array}$ & $\begin{array}{c}\text { Unadjusted } \\
\text { OR (95\% CI) } \\
\text { p value }\end{array}$ & $\begin{array}{c}\text { Adjusted } \\
\text { OR }(95 \% \text { CI) } \\
\text { p value } \\
\end{array}$ \\
\hline Age & & & & $<0.001$ & & & & \\
\hline $24-59$ months & $45(1)$ & $1657(37)$ & $2784(62)$ & & $\begin{array}{c}0.72(0.53,1.00) \\
0.046\end{array}$ & $\begin{array}{c}0.82(0.59,1.23) \\
0.214\end{array}$ & $\begin{array}{c}2.12(1.97,2.26) \\
<0.001\end{array}$ & $\begin{array}{c}1.83(1.70,1.97) \\
<0.001\end{array}$ \\
\hline $12-23$ months & $159(2)$ & $3691(51)$ & $3408(47)$ & & $\begin{array}{c}1.15(0.95,1.40) \\
0.165\end{array}$ & $\begin{array}{c}1.17(0.95,1.42) \\
0.133\end{array}$ & $\begin{array}{c}1.16(1.09,1.23) \\
<0.001\end{array}$ & $\begin{array}{c}1.26(1.06,1.20) \\
<0.001\end{array}$ \\
\hline $0-11$ months & $304(2)$ & $8107(54)$ & $6468(44)$ & & 1.00 & 1.00 & 1.00 & 1.00 \\
\hline Sex & & & & $<0.001$ & & & & \\
\hline Male & $331(65)$ & $8082(60)$ & $8000(63)$ & & $\begin{array}{c}1.24(1.03,1.49) \\
0.022\end{array}$ & $\begin{array}{c}1.31(1.08,1.57) \\
0.006\end{array}$ & $\begin{array}{c}1.14(1.08,1.20) \\
<0.001\end{array}$ & $\begin{array}{c}1.14(1.07,1.20) \\
<0.001\end{array}$ \\
\hline Maternal literacy & & & & $<0.001$ & & & & \\
\hline Literate & $487(96)$ & $9794(73)$ & $5774(46)$ & & $\begin{array}{c}8.67(5.69,13.44) \\
<0.001\end{array}$ & $\begin{aligned} 3.66 & (2.31,5.79) \\
& <0.001\end{aligned}$ & $\begin{array}{c}0.31(0.29,0.33) \\
<0.001\end{array}$ & $\begin{array}{c}0.60(0.56,0.64) \\
<0.001\end{array}$ \\
\hline Illiterate & $21(4)$ & $3660(27)$ & $6889(54)$ & & 1.00 & 1.00 & 1.00 & 1.00 \\
\hline Family size & & & & $<0.001$ & & & & \\
\hline >mean; (5) & $213(42)$ & $5058(38)$ & $4330(34)$ & & $\begin{array}{c}0.83(0.69,0.99) \\
0.048\end{array}$ & $\begin{array}{c}1.13(0.93,1.36) \\
0.219\end{array}$ & $\begin{array}{c}1.16(1.10,1.220 \\
<0.001\end{array}$ & $\begin{array}{c}0.90(0.85,0.96) \\
<0.001\end{array}$ \\
\hline$\leq$ mean; (5) & $295(58)$ & $8397(62)$ & $8330(66)$ & & 1.00 & 1.00 & 1.00 & 1.00 \\
\hline Residence & & & & $<0.001$ & & & & \\
\hline $\begin{array}{l}\text { Non-slum } \\
\text { urban }\end{array}$ & $504(99)$ & $12662(94)$ & $10676(84)$ & & $\begin{array}{c}7.89(2.94,21.16) \\
<0.001\end{array}$ & $\begin{array}{c}2.01(0.74,5.51) \\
0.174\end{array}$ & $\begin{array}{c}0.33(0.31,0.37) \\
<0.001\end{array}$ & $\begin{array}{c}0.73(0.67,0.81) \\
<0.001\end{array}$ \\
\hline Slum urban & $4(1)$ & $793(6)$ & $1984(16)$ & & 1.00 & 1.00 & 1.00 & 1.00 \\
\hline $37-\leq 73$ US\$ & 94 (19) & 4457 (33) & $4056(32)$ & & $\begin{array}{c}2.74(1.77,4.24) \\
<0.001\end{array}$ & $\begin{array}{c}1.59(1.06,2.52) \\
0.047\end{array}$ & $\begin{array}{c}0.48(0.45,0.51) \\
<0.001\end{array}$ & $\begin{array}{c}0.72(0.68,0.78) \\
<0.001\end{array}$ \\
\hline$\leq 37$ US\$ & $26(5)$ & $3375(25)$ & $6411(51)$ & & 1.00 & 1.00 & 1.00 & 1.00 \\
\hline Wealth quintile & & & & $<0.001$ & & & & \\
\hline High income & $204(61)$ & $3756(28)$ & $1243(10)$ & & $\begin{array}{c}10.83(6.06 \\
19.34)<0.001\end{array}$ & $\begin{array}{c}1.99(1.02,3.82) \\
0.044\end{array}$ & $\begin{array}{c}0.15(0.13,0.16) \\
<0.001\end{array}$ & $\begin{array}{c}0.35(0.31,0.40) \\
<0.001\end{array}$ \\
\hline Upper middle & 94 (19) & $3375(25)$ & $2144(17)$ & & $\begin{array}{c}3.73(2.04,6.82) \\
<0.001\end{array}$ & $\begin{array}{c}0.93(0.48,1.81) \\
0.837\end{array}$ & $\begin{array}{c}0.28(0.26,0.30) \\
<0.001\end{array}$ & $\begin{array}{c}0.55(0.40,0.61) \\
<0.001\end{array}$ \\
\hline $\begin{array}{l}\text { Middle } \\
\text { income }\end{array}$ & $66(13)$ & 2459 (19) & $2292(18)$ & & $\begin{array}{c}3.59(1.94,6.67) \\
<0.001\end{array}$ & $\begin{array}{c}1.22(0.63,2.34) \\
0.559\end{array}$ & $\begin{array}{c}0.41(0.38,0.447) \\
<0.001\end{array}$ & $\begin{array}{c}0.66(0.60,0.73) \\
<0.001\end{array}$ \\
\hline Lower middle & $23(5)$ & 2067 (16) & $3232(26)$ & & $\begin{array}{c}1.68(0.85,3.35) \\
0.137\end{array}$ & $\begin{array}{c}0.96(0.48,1.93) \\
0.905\end{array}$ & $\begin{aligned} 0.69 & (0.64,0.75) \\
& <0.001\end{aligned}$ & $\begin{array}{c}0.86(0.79,0.94) \\
0.001\end{array}$ \\
\hline Low income & $12(2)$ & $1606(12)$ & $3636(29)$ & & 1.00 & 1.00 & 1.00 & 1.00 \\
\hline Sanitary toilet & & & & $<0.001$ & & & & \\
\hline Sanitary & $444(87)$ & $8854(66)$ & $6116(48)$ & & $\begin{aligned} 3.61 & (2.77,4.70) \\
& <0.001\end{aligned}$ & $\begin{array}{c}1.47(1.07,2.01) \\
0.016\end{array}$ & $\begin{array}{c}0.49(0.46,0.51) \\
<0.001\end{array}$ & $\begin{array}{c}1.14(1.07,1.22) \\
<0.001\end{array}$ \\
\hline Non-sanitary & $64(13)$ & $4601(34)$ & $6544(52)$ & & 1.00 & 1.00 & 1.00 & 1.00 \\
\hline $\begin{array}{l}\text { Drink boiled } \\
\text { water }\end{array}$ & & & & $<0.001$ & & & & \\
\hline Yes & $266(52)$ & $4502(34)$ & $2254(18)$ & & $\begin{array}{c}2.19(1.83,2.61) \\
<0.001\end{array}$ & $\begin{array}{c}0.95(0.77,1.17) \\
0.626\end{array}$ & $\begin{array}{c}0.43(0.41,0.46) \\
<0.001\end{array}$ & $\begin{array}{c}0.99(0.92,1.06) \\
0.777\end{array}$ \\
\hline No & $242(48)$ & $8953(64)$ & $10406(82)$ & & 1.00 & 1.00 & 1.00 & 1.00 \\
\hline
\end{tabular}

N.B: Well-nourished considered as reference category. 
Table 2. Socio-demographic characteristics and their association with overweight/obese and malnourished status among individuals aged 5 - 19 years.

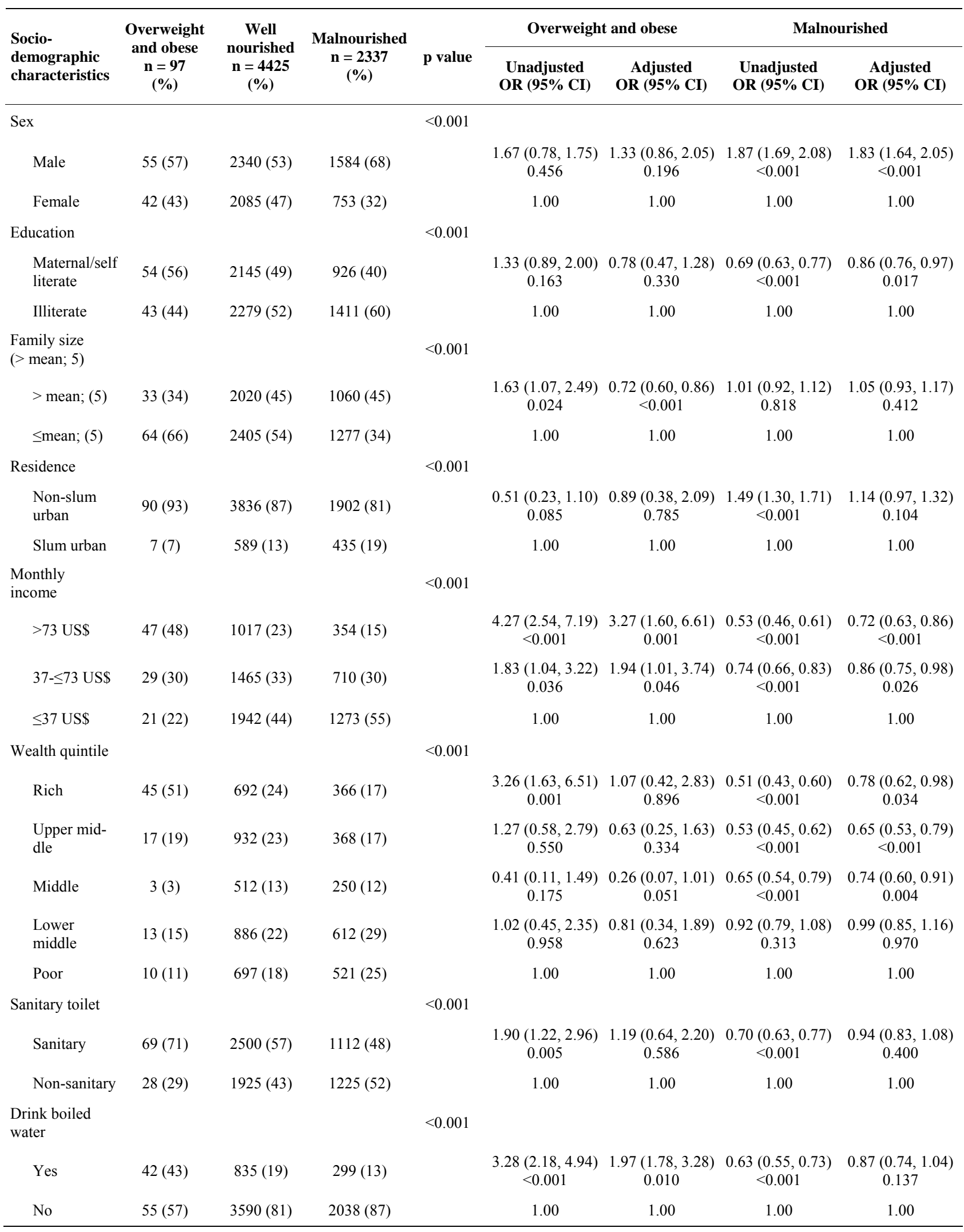

N.B: Well-nourished considered as reference category. 
Table 3. Socio-demographic characteristics and their association with overweight/obese and malnourished status among individuals aged more than 19 years.

\begin{tabular}{|c|c|c|c|c|c|c|c|c|}
\hline \multirow{2}{*}{$\begin{array}{l}\text { Socio- } \\
\text { demographic } \\
\text { characteristics }\end{array}$} & \multirow{2}{*}{$\begin{array}{c}\text { Overweight } \\
\text { and obese } \\
\begin{array}{c}n=1324 \\
(\%)\end{array}\end{array}$} & \multirow{2}{*}{$\begin{array}{c}\text { Well } \\
\text { nourished } \\
\text { n = 8467 } \\
(\%)\end{array}$} & \multirow{2}{*}{$\begin{array}{c}\text { Malnourished } \\
\text { n = 6216 } \\
(\%)\end{array}$} & \multirow{2}{*}{ p value } & \multicolumn{2}{|c|}{ Overweight and obese } & \multicolumn{2}{|c|}{ Malnourished } \\
\hline & & & & & $\begin{array}{c}\text { Unadjusted } \\
\text { OR (95\% CI) }\end{array}$ & $\begin{array}{c}\text { Adjusted } \\
\text { OR (95\% CI) }\end{array}$ & $\begin{array}{c}\text { Unadjusted } \\
\text { OR (95\% CI) }\end{array}$ & $\begin{array}{c}\text { Adjusted } \\
\text { OR (95\% CI) }\end{array}$ \\
\hline Sex & & & & $<0.001$ & & & & \\
\hline Male & $572(43)$ & $4852(57)$ & $3610(58)$ & & $\begin{array}{c}0.50(0.49,0.62) \\
\quad<0.001\end{array}$ & $\begin{array}{c}0.56(0.49,0.65) \\
<0.001\end{array}$ & $\begin{array}{c}1.03(0.96,1.10) \\
0.395\end{array}$ & $\begin{array}{c}1.10(1.01,1.19) \\
0.022\end{array}$ \\
\hline Female & $752(57)$ & $3615(43)$ & $2606(42)$ & & 1.00 & 1.00 & 1.00 & 1.00 \\
\hline Self literacy & & & & $<0.001$ & & & & \\
\hline Literate & $820(70)$ & $4660(57)$ & $2548(42)$ & & $\begin{array}{c}1.78(1.56,2.04) \\
<0.001\end{array}$ & $\begin{array}{c}1.12(0.95,1.29) \\
0.182\end{array}$ & $\begin{array}{c}0.53(0.49,0.57) \\
<0.001\end{array}$ & $\begin{array}{c}0.76(0.71,0.83) \\
<0.001\end{array}$ \\
\hline Illiterate & $344(30)$ & $3486(43)$ & $3584(58)$ & & 1.00 & 1.00 & 1.00 & 1.00 \\
\hline Residence & & & & $<0.001$ & & & & \\
\hline $\begin{array}{l}\text { Non-slum } \\
\text { urban }\end{array}$ & $1287(97)$ & $7704(91)$ & $5172(83)$ & & $\begin{array}{c}3.15(2.25,4.41) \\
<0.001\end{array}$ & $\begin{array}{c}1.25(0.87,1.81) \\
0.226\end{array}$ & $\begin{array}{c}0.50(0.46,0.56) \\
<0.001\end{array}$ & $\begin{array}{c}0.85(0.76,0.95) \\
0.006\end{array}$ \\
\hline Sum urban & $37(3)$ & $763(9)$ & $1044(17)$ & & 1.00 & 1.00 & 1.00 & 1.00 \\
\hline $\begin{array}{l}\text { Monthly income } \\
>100 \text { US\$ }\end{array}$ & & & & $<0.001$ & & & & \\
\hline$>73$ US\$ & $799(68)$ & $3121(38)$ & $1220(20)$ & & $\begin{array}{c}5.58(4.63,6.78) \\
<0.001\end{array}$ & $\begin{array}{c}2.47(1.99,3.07) \\
\quad<0.001\end{array}$ & $\begin{array}{c}0.31(0.28,0.34) \\
<0.001\end{array}$ & $\begin{array}{c}0.52(0.47,0.58) \\
<0.001\end{array}$ \\
\hline $37-\leq 73$ US\$ & $231(20)$ & $2189(27)$ & $1563(25)$ & & $\begin{aligned} 2.29 & (1.87,2.81) \\
& <0.001\end{aligned}$ & $\begin{array}{c}1.43(1.15,1.78) \\
0.001\end{array}$ & $\begin{array}{c}0.57(0.53,0.62) \\
<0.001\end{array}$ & $\begin{array}{c}0.76(0.69,0.82) \\
<0.001\end{array}$ \\
\hline$\leq 37$ US\$ & $144(12)$ & $2882(35)$ & $3393(55)$ & & 1.00 & 1.00 & 1.00 & 1.00 \\
\hline Wealth quintile & & & & $<0.001$ & & & & \\
\hline Upper middle & $297(26)$ & $1896(24)$ & $941(16)$ & & $\begin{aligned} 4.90 & (3.42,7.01) \\
& <0.001\end{aligned}$ & $\begin{array}{c}2.89(1.94,4.31) \\
<0.001\end{array}$ & $\begin{array}{c}0.33(0.29,0.37) \\
<0.001\end{array}$ & $\begin{array}{c}0.51(0.45,0.58) \\
<0.001\end{array}$ \\
\hline Middle & $146(13)$ & $1675(21)$ & $1262(21)$ & & $\begin{array}{c}2.73(1.87,3.97) \\
<0.001\end{array}$ & $\begin{array}{c}1.98(1.32,2.96) \\
0.001\end{array}$ & $\begin{array}{c}0.50(0.45,0.55) \\
<0.001\end{array}$ & $\begin{array}{c}0.66(0.59,0.75) \\
<0.001\end{array}$ \\
\hline Lower middle & $80(7)$ & $1488(19)$ & $1496(25)$ & & $\begin{array}{c}1.68(1.12,2.52) \\
0.012\end{array}$ & $\begin{array}{c}1.33(0.88,2.02) \\
0.176\end{array}$ & $\begin{array}{c}0.66(0.60,0.74) \\
<0.001\end{array}$ & $\begin{array}{c}0.78(0.70,0.87) \\
<0.001\end{array}$ \\
\hline Poor & $35(3)$ & $1094(13)$ & $1658(28)$ & & 1.00 & 1.00 & 1.00 & 1.00 \\
\hline Sanitary toilet & & & & $<0.001$ & & & & \\
\hline Sanitary & $1114(84)$ & $5524(65)$ & $3102(50)$ & & $\begin{aligned} 2.61 & (2.23,3.06) \\
& <0.001\end{aligned}$ & $\begin{array}{c}1.16(0.96,1.40) \\
0.115\end{array}$ & $\begin{array}{c}0.55(0.51,0.59) \\
<0 . .001\end{array}$ & $\begin{array}{c}0.96(0.89,1.04) \\
0.311\end{array}$ \\
\hline Non-sanitary & $210(16)$ & $2943(35)$ & $3114(50)$ & & 1.00 & 1.00 & 1.00 & 1.00 \\
\hline $\begin{array}{l}\text { Drink boiled } \\
\text { water }\end{array}$ & & & & $<0.001$ & & & & \\
\hline Yes & $590(45)$ & $2108(25)$ & $833(13)$ & & $\begin{array}{c}2.32(2.05,2.64) \\
\quad<0.001\end{array}$ & $\begin{array}{c}1.02(0.88,1.18) \\
0.831\end{array}$ & $\begin{array}{c}0.49(0.45,0.53) \\
<0.001\end{array}$ & $\begin{array}{c}0.95(0.85,1.05) \\
0.336\end{array}$ \\
\hline No & $722(55)$ & $6359(75)$ & $5383(87)$ & & 1.00 & 1.00 & 1.00 & 1.00 \\
\hline Smoking & & & & $<0.001$ & & & & \\
\hline Yes & $136(12)$ & $1760(22)$ & $1620(26)$ & & $\begin{array}{c}0.48(0.40,0.58) \\
\quad<0.001\end{array}$ & $\begin{array}{c}0.72(0.58,0.88) \\
0.002\end{array}$ & $\begin{array}{c}1.29(1.02,1.40) \\
<0.001\end{array}$ & $\begin{array}{c}1.16(1.06,1.27) \\
0.001\end{array}$ \\
\hline No & $1038(88)$ & $6432(78)$ & $4556(74)$ & & 1.00 & 1.00 & 1.00 & 1.00 \\
\hline
\end{tabular}

N.B: Well-nourished considered as reference category. 
The other alarming observation was an increasing trend of nutritional status (mean weight-for-age $\mathrm{z}$-score, BMI-for-z score and BMI) among the normal weight individuals irrespective of age and sex. The Dhaka Hospital is the largest diarrheal disease hospital in Bangladesh, and receives patients from the urban and peri-urban area of Dhaka. Increased proportion of overweight and obese individuals over the two decades (1993 to 2011) and increased average BMI among well-nourished individuals makes an iceberg impression about early signs of the increasing burden of overweight and obesity among the general population. Bangladesh is a country in transition and the national GDP per capita of Bangladesh is gradually increasing [35]. This gross economic improvement may have an impact on the overall behavioral change in general population, which has also been supported by our present study as evidenced by an increase in the number of individuals with higher economic status.

The prevalence of overweight and obesity is gradually increasing in all age groups, and establishment of effective preventive measures requires an understanding and appreciation of the magnitude of the problems and its consequences by health planners and policymakers. The findings from the present study were comparable with the global as well as Asian context [36]. An emphasis on education campaigns among general population, with several national programmes like "Fit and Trim" urgently need to be introduced [37] to increase awareness of the adverse effects and consequences of overweight and obesity. At the same time, national guidelines are needed to mitigate the problem of overweight and obesity in children and adolescents [38]. The size of open spaces is rapidly reducing in this increasingly populated city. The built environment can have a significant impact on physical activity behaviours, and in planning for the expansion of the city, provisions for open spaces for physical exercise of the residents should seriously be taken into consideration.

\section{Limitations}

This study was conducted among people attending a large diarrheal disease health facility, and may not be representative of the general population. However, the hospital provides cost-free treatment and it is accessible by all people, irrespective of their socioeconomic or other status. Strengths of the study include measured height and weight, using a large, systematic sample and unbiased sampling of the surveillance system.

\section{Conclusion}

Overweight and obesity are growing public health concerns in Bangladesh. In our present analyses, we noted a significant increase in the proportion of overweight and obese patients presenting at the urban diarrheal disease hospital over the last two decades. These changes may be in part due to improved socio-economic conditions, differences in food behaviours and other lifestyle factors. Further studies are needed to understand the national burden of obesity and overweight. Studies examining the nutrition, physical activity and lifestyle behaviours of obese and overweight individuals may help to elucidate individual characteristics associated with the increased prevalence of overweight in Bangladesh. Additionally, examining the host characteristics that would predict susceptibility of the overweight and obese population to diarrheal illnesses and other acute diseases common in Bangladesh may be of interest.

\section{Acknowledgements}

Hospital surveillance was funded by icddr,b and the Government of the People's Republic of Bangladesh through IHP-HNPRP. icddr,b acknowledges with gratitude the commitment of the Government of the People's Republic of Bangladesh to the icddr,b's research efforts. icddr,b also gratefully acknowledges the following donors who provide unrestricted support to the Centre's research efforts: Australian Agency for International Development (AusAID), Government of the People's Republic of Bangladesh, Canadian International Development Agency (CIDA), Embassy of the Kingdom of the Netherlands (EKN), Swedish International Development Cooperation Agency (Sida), Swiss Agency for Development and Cooperation (SDC), and Department for International Development, UK (DFID).

\section{REFERENCES}

[1] Z. Y. Zhang and M. W. Wang, "Obesity, a Health Burden of a Global Nature," Acta Pharmacologica Sinica, Vol. 33, No. 2, 2012, pp. 145-147.

[2] C. J. Stein and G. A. Colditz, "The Epidemic of Obesity," The Journal of Clinical Endocrinology \& Metabolism, Vol. 89, No. 6, 2004, pp. 2522-2525. doi: $10.1210 /$ jc. $2004-0288$

[3] P. G. Kopelman, "Obesity as a Medical Problem," Nature, Vol. 404, No. 6778, 2000, pp. 635-643.

[4] A. E. Field, E. H. Coakley, A. Must, J. L. Spadano, N. Laird, W. H. Dietz, E. Rimm and G. A. Colditz, "Impact of Overweight on the Risk of Developing Common Chronic Diseases during a 10-Year Period," Archives of Internal Medicine, Vol. 161, No. 13, 2001, pp. 1581-1586.

[5] D. M. Nguyen and H. B. El-Serag, "The Big Burden of Obesity," Gastrointestinal Endoscopy, Vol. 70, No. 4, 2009, pp. 752-757.

[6] B. M. Popkin, "Global Nutrition Dynamics: The World Is Shifting Rapidly toward a Diet Linked with Noncommunicable Diseases," American Journal of Clinical Nutrition, Vol. 84, No. 2, 2006, pp. 289-298. 
[7] D. Thompson and A. M. Wolf, "The Medical-Care Cost Burden of Obesity," Obesity Reviews, Vol. 2, No. 3, 2001, pp. 189-197. doi:10.1046/j.1467-789x.2001.00037.x

[8] S. D. Mathias, C. L. Williamson, H. H. Colwell, M. G. Cisternas, D. J. Pasta, B. S. Stolshek and D. L. Patrick, "Assessing Health-Related Quality-of-Life and Health State Preference in Persons with Obesity: A validation Study," Quality of Life Research, Vol. 6, No. 4, 1997, pp. 311-322. doi:10.1023/A:1018475108460

[9] J. Karlsson, L. Sjostrom and M. Sullivan, "Swedish Obese Subjects (Sos) - An Intervention Study of Obesity. Measuring Psychosocial Factors and Health by Means of ShortForm Questionnaires. Results from a Method Study," Journal of Clinical Epidemiology, Vol. 48, No. 6, 1995, pp. 817-823.

[10] A. Ramachandran and C. Snehalatha, "Rising Burden of Obesity in Asia," Journal of Obesity, 2010. doi:10.1155/2010/868573

[11] Y. Wu, "Overweight and Obesity in China," BMJ, Vol. 333, No. 7564, 2006, pp. 362-363.

[12] P. Boffetta, D. McLerran, Y. Chen, M. Inoue, R. Sinha, J. He, P. C. Gupta, S. Tsugane, F. Irie, A. Tamakoshi, Y. T. Gao, X. O. Shu, R. Wang, I. Tsuji, S. Kuriyama, K. Matsuo, H. Satoh, C. J. Chen, J. M. Yuan, K. Y. Yoo, H. Ahsan, W. H. Pan, D. Gu, M. S. Pednekar, S. Sasazuki, T. Sairenchi, G. Yang, Y. B. Xiang, M. Nagai, H. Tanaka, Y. Nishino, S. L. You, W. P. Koh, S. K. Park, C. Y. Shen, M. Thornquist, D. Kang, B. Rolland, Z. Feng, W. Zheng and J. D. Potter, "Body Mass Index and Diabetes in Asia: A Cross-Sectional Pooled Analysis of 900,000 Individuals in the Asia Cohort Consortium," PLoS One, Vol. 6, No. 6, 2011, Article ID: e19930. doi:10.1371/journal.pone.0019930

[13] Y. Balarajan and E. Villamor, "Nationally Representative Surveys Show Recent Increases in the Prevalence of Overweight and Obesity among Women of Reproductive Age in Bangladesh, Nepal, and India," Journal of Nutrition, Vol. 139, No. 11, 2009, pp. 2139-2144.

[14] F. Mohsin, S. Tayyeb, A. Baki, S. Sarker, B. Zabeen, T. Begum, K. Azad and N. Nahar, "Prevalence of Obesity among Affluent School Children in Dhaka," Mymensingh Medical Journal, Vol. 19, No. 4, 2010, pp. 549-554.

[15] M. de Onis, C. Garza, A. W. Onyango and M. F. RollandCachera, "Who Growth Standards for Infants and Young Children," Archives de Pediatrie, Vol. 16, No. 1, 2009, pp. 47-53.

[16] Public Health Observatories, "A Simple Guide to Classifying Body Mass Index in Children," National Obesity Observatory, Public Health Observatories, England, 2011.

[17] B. A. Swinburn, I. Caterson, J. C. Seidell and W. P. James, "Diet, Nutrition and the Prevention of Excess Weight Gain and Obesity," Public Health Nutrition, Vol. 7, No. 1A, 2004, pp. 123-146.

[18] R. R. Briefel, M. K. Crepinsek, C. Cabili, A. Wilson and P. M. Gleason, "School Food Environments and Practices Affect Dietary Behaviors of US Public School Children," Journal of the American Dietetic Association, Vol. 109, No. S2, 2009, pp. S91-S107.

[19] World Health Organization, "Obesity and Overweight.
Fact Sheet," World Health Organization, Geneva, 2012.

[20] P. T. Martikainen and M. G. Marmot, "Socioeconomic Differences in Weight Gain and Determinants and Consequences of Coronary Risk Factors," American Journal of Clinical Nutrition, Vol. 69, No. 4, 1999, pp. 719-726.

[21] P. H. Lahmann, L. Lissner, B. Gullberg and G. Berglund, "Sociodemographic Factors Associated with Long-Term Weight Gain, Current Body Fatness and Central Adiposity in Swedish Women," International Journal of Obesity and Related Metabolic Disorders, Vol. 24, No. 6, 2000, pp. 685-694. doi:10.1038/sj.ijo.0801219

[22] J. Stillwell, N. Finney and M. van Ham, "Ethnic Differences in Physical Activity and Obesity," The University of Manchester, Manchester, 2009.

[23] A. Case and A. Menendez, "Sex Differences in Obesity Rates in Poor Countries: Evidence from South Africa," Economics and Human Biology, Vol. 7, No. 3, 2009, pp. 271-228. doi:10.1016/i.ehb.2009.07.002

[24] A. T. Ali and N. J. Crowther, "Factors Predisposing to Obesity: A Review of the Literature," Journal of Endocrinology, Metabolism and Diabetes of South Africa, Vol. 14, No. 2, 2009.

[25] South Asia Urban Growth, "South Asia e World Population Day e July 11 (South Asia Urban Growth) Web. Worldbank.Org countries south asia."

[26] Mike Davis, "Planet of Slums," 2006.

[27] N. Kunzli, M. Jerrett, R. Garcia-Esteban, X. Basagana, B. Beckermann, F. Gilliland, M. Medina, J. Peters, H. N. Hodis and W. J. Mack, "Ambient Air Pollution and the Progression of Atherosclerosis in Adults," PLoS One, Vol. 5, No. 2, 2010, Article ID: e9096. doi:10.1371/journal.pone.0009096

[28] M. Bauer, S. Moebus, S. Mohlenkamp, N. Dragano, M. Nonnemacher, M. Fuchsluger, C. Kessler, H. Jakobs, M. Memmesheimer, R. Erbel, K. H. Jockel and B. Hoffmann, "Urban Particulate Matter Air Pollution Is Associated with Subclinical Atherosclerosis: Results from the Hnr (Heinz Nixdorf Recall) Study," Journal of the American College of Cardiology, Vol. 56, No. 22, 2010, pp. 18031808.

[29] M. Clearfield, “Another Inconvenient Truth: Combining the Risks from Obesity and Metabolic Syndrome with Global Warming," Current Atherosclerosis Reports, Vol. 10, No. 4, 2008, pp. 273-276. doi:10.1007/s11883-008-0041-Z

[30] D. T. Eisenberg, C. W. Kuzawa and M. G. Hayes, "Worldwide Allele Frequencies of the human Apolipoprotein e Gene: Climate, Local Adaptations, and Evolutionary History," American Journal of Physical Anthropology, Vol. 143, No. 1, 2010, pp. 100-111. doi:10.1002/ajpa.21298

[31] L. Nasreddine, N. Hwalla, A. Sibai, M. Hamze and D. Parent-Massin, "Food Consumption Patterns in an Adult Urban Population in Beirut, Lebanon," Public Health Nutrition, Vol. 9, No. 2, 2006, pp. 194-203.

[32] E. Becquey, M. Savy, P. Danel, H. B. Dabire, S. Tapsoba and Y. Martin-Prevel, "Dietary Patterns of Adults Living in Ouagadougou and Their Association with Overweight," Nutrition Journal, Vol. 9, No. 13, 2010, p. 13. 
[33] C. L. Ogden, M. D. Carroll, L. R. Curtin, M. A. McDowell, C. J. Tabak and K. M. Flegal, "Prevalence of Overweight and Obesity in the United States, 1999-2004," JAMA, Vol. 295, No. 13, 2006, pp. 1549-1555.

[34] S. Agrawal and P. K. Agrawal, "Does Contraceptive Use Effect Overweight/Obesity among Indian Women? Findings from a Nationwide Cross Sectional Survey," Research and Practice in Social Sciences, Vol. 7, No. 1, 2011, pp. 17-32.

[35] 2012.

http://www.Indexmundi.Com/facts/indicators/ny.Gdp.Pca p.Pp.Cd
[36] N. Gupta, K. Goel, P. Shah and A. Misra, "Childhood Obesity in Developing Countries: Epidemiology, Determinants, and Prevention," Endocrine Reviews, Vol. 33, No. 1, 2012, pp. 48-70.

[37] C. M. Toh, J. Cutter and S. K. Chew, "School Based Intervention Has Reduced Obesity in Singapore," BMJ, Vol. 324, No. 7334, 2002, p. 427. doi:10.1136/bmj.324.7334.427/a

[38] S. M. D. Sidik and R. Ahmad, "Childhood Obesity: Contributing Factors, Consequences and Intervention," Malaysian Journal of Nutrition, Vol. 10, No. 1, 2004, pp. $13-22$. 